\title{
Audit committee effectiveness, internal audit function and sustainability reporting practices
}

\author{
Zainabu Tumwebaze, Juma Bananuka, Twaha Kigongo Kaawaase, \\ Caroline Tirisa Bonareri and Fred Mutesasira \\ Department of Accounting, Makerere University Business School, \\ Makerere University, Kampala, Uganda
}

\section{Sustainability reporting practices}

Received 15 March 2021 Revised 7 June 2021 23 August 2021

Accepted 11 September 2021

\begin{abstract}
Purpose - The purpose of this study is to examine the association between audit committee effectiveness (ACE), internal audit function (IAF) and sustainability reporting practices.

Design/methodology/approach - Using a cross-sectional and correlational design, useable questionnaires were received from 48 financial services firms in Uganda. The data were analyzed using Statistical Package for Social Sciences.

Findings - results indicate that ACE and IAF are positively and significantly associated with sustainability reporting practices. ACE and IAF are more significantly associated with economic and social indicators than environmental sustainability indicators.

Research limitations/implications - In terms of practice, it is no longer a matter of having internal auditors and audit committees in place but rather those who are mindful of the welfare of society and the natural environment. The effectiveness of the board audit committee and a functioning internal audit can be assessed in terms of their recommendations and decisions regarding improvements in the welfare of society and the natural environment in addition to the traditionally known performance benchmarks.

Practical implications - The study focuses on only financial services firms in Uganda, and this is a small sample. Future studies may focus on larger samples to enable comparison of the results.

Originality/value - This study provides insights on the initial understanding of the association between ACE, IAF and sustainability reporting practices using evidence from a developing African country - Uganda.
\end{abstract}

Keywords Sustainability reporting practices, Audit committee effectiveness, Internal audit function,

Legitimacy theory, Agency theory, Uganda

Paper type Research paper

\section{Introduction}

Over the years, there is growing interest in sustainability reporting practices among academicians, practitioners and policy makers, though evidence from developing countries is scant (Tauringana, 2021). Sustainability reporting provides a platform for provision of information on economic, social and environmental performance to various stakeholders unlike the traditional financial reporting which provides information on only financial performance (De Villiers and Sharma, 2020). Sustainability reporting is one of the mechanisms to promote accountability for the use of natural resources in provision of

(C) Zainabu Tumwebaze, Juma Bananuka, Twaha Kigongo Kaawaase, Caroline Tirisa Bonareri and Fred Mutesasira. Published in Asian Journal of Accounting Research. Published by Emerald Publishing Limited. This article is published under the Creative Commons Attribution (CC BY 4.0) licence. Anyone may reproduce, distribute, translate and create derivative works of this article (for both commercial and non-commercial purposes), subject to full attribution to the original publication and authors. The full terms of this licence may be seen at http://creativecommons.org/licences/by/4.0/legalcode

The authors are grateful for the financial support received from Government of Uganda through Makerere University Business School under the Faculty of Commerce research funding. The authors wish to thank the respondents for being cooperative. Thank you also to the Editors and anonymous reviewers of Asian Journal of Accounting Research for the constructive comments and timely feedback.

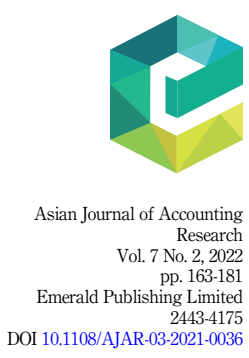


AJAR

7,2

164

products or services among firms, improves company image, motivates the workforce and enables competitiveness (Journeault et al., 2021; Orazalin and Mahmood, 2018; Cho et al., 2015). Sustainability reporting contributes to the achievement of sustainability and sustainable development goals (SDGs). The achievement of SDGs in every country is made possible through companies' reporting practices which are vital for enhancing decisionmaking. One of such companies that should improve sustainability reporting practices are financial services firms. Whereas manufacturing firms are known for polluting the environment through release of gas emissions and wastes to the environment, financial services firms are known for provision of funding to the manufacturing firms. This means that if financial services firms such as banks can require sustainability reports for manufacturing firms to access funding, then it is possible that all entities will prepare sustainability reports.

The Global Reporting Initiative (GRI) is the most popular organization for provision of guidelines for sustainability reporting. In 2016, GRI released the GRI standards and became effective in 2018. This was because of the desire to have sustainability reports that not only capture the good news but also the negative effects of company activities. Earlier scholars such as Cho et al. (2015) indicated that there is a huge gap between sustainability talk and actions which means that firms were preparing sustainability reports not fully following the GRI guidelines/standards. With the emergence of the GRI standards 2016, there is a likelihood of relief if companies can adopt such standards. Presently, there is a move by the IFRS foundation to develop sustainability reporting standards which will be based on the existing works of global organizations such as GRI. Unfortunately, the IFRS foundation move on sustainability reporting practices is investor focused rather than society focused as it has been. Such a move is likely to worsen the situation. The current GRI standards once fully adopted by companies, it is likely that the planet (source of raw materials), people (market for company products) and profits (share holders' wealth) will be fully accounted for by respective organizations. Otherwise, there are still a number of climate-related challenges such as prolonged droughts, high temperatures, increased pollution and diseases in most parts of the world (World Meteorological Organization, 2021).

In Africa, there is some progress on sustainability reporting, especially in South Africa where it has been made mandatory. In Uganda, sustainability reporting practices are still low and voluntary. By December, 2019, there were only 10 companies in Uganda that had their sustainability reports uploaded on GRI website (GRI, 2019) of which only two companies prepared their sustainability reports in compliance with the GRI standards. The sustainability reports of five companies are categorized as non GRI reports, and the other companies' reports are categorized as GRI citing. Based on the GRI (2019), out of the 10 companies having their sustainability reports uploaded on the GRI website, only four (about $40 \%$ ) companies are financial services firms. This means that of the 67 financial services firms, only $6 \%$ prepare sustainability reports and upload them on the GRI website. However, on checking individual websites of financial services firms, we found that more firms were preparing sustainability reports but were not uploading them on the GRI website. Such firms include Centenary Bank, DFCU bank and Kenya Commercial Bank among others. According to Tauringana (2021), $80 \%$ of members of Uganda Manufacturers' Association (UMA) prepare sustainability reports. This study believes that corporate governance mechanisms such as the audit committee effectiveness (ACE) and the internal audit function (IAF) are responsible for promoting sustainability reporting practices in financial services firms.

From literature, there are studies that focus on corporate governance mechanisms and sustainability reporting (see, Amran et al., 2014; Shamil et al., 2014; Amidjaya and Widgdo, 2019; Karaman et al., 2020; Correa-Garcia et al., 2020). Amidjaya and Widagdo (2019) found that sustainability reporting is influenced by corporate governance, foreign ownership and family ownership using evidence from Indonesian banks. Further, Amran et al. (2014) found 
that governance structures, especially the board of directors and corporate social responsibility strategies, are significant for sustainability reporting quality in the Asian Pacific region. However, Amran et al. (2014) indicated that there is need to examine the association between ACE and sustainability reporting quality. Earlier, the King III report of South Africa (2009) had commended the audit committee to review issues of sustainability disclosures and ensure credibility and reliability of the information disclosed in the sustainability reports. Further, using evidence from 59-listed banks from the Gulf Cooperation Countries (GCC), Buallay and Al-Ajmi (2019) found that audit committee size, independence and meetings have significant and positive relationship with sustainability reporting practices.

Studies that link ACE in terms of their role performance and IAF to sustainability reporting practices are scarce on the African scene, especially Uganda. Whereas Dominic and Martinov-Bennie (2015) documented that IAF is involved in sustainability reporting by providing assurance on the economic, social and governance of a firm, their study was conducted from Australia which is a developed country as compared to Uganda. Audit committees are largely known for ensuring quality of the reports. However, an effective audit committee reviews and makes recommendations on the financial and nonfinancial information of the company. In countries such as Uganda, audit committees are expected to participate in risk management processes and as such if there are risks associated with lack or poor sustainability reporting practices, the audit committee is expected to report such to the entire board. In the Uganda's Financial Institutions Act of 2004, the audit committee is part of the board. The board is the overall governing body of the company and as such any decisions made by the board are bound to the company. We therefore argue that the audit committee is involved in making decisions regarding the adoption of or improvement in sustainability reporting practices. For the IAF, one of the roles it plays is to ensure that there is regulatory compliance and risk management. In executing its role on regulatory compliance, the internal audit is expected to ensure that the organization complies with the environmental laws. The environmental laws applicable in Uganda are the National Environmental Act of 2019 which provides for several disclosure requirements such as disclosure on the usage of hazardous materials and waste management.

Uganda is one of those countries with a high population growth rate and somehow relaxed policies on environmental protection. This means that the internal mechanisms such as the IAF and the audit committees have to play a big role to ensure that environmental-related issues are taken care of in the process of entity operations. Given that Uganda is an emerging country and encouraging foreign investors to come into the country, the effect of such investors' activities on the environment are handled gently, and as a result, it is expected that in the next about 100 years from 2016, Uganda will have no wetland left if the current trend is maintained.

In this study, we build on the existing literature such as Amran et al. (2014) by conducting a study on the association between ACE, IAF and sustainability reporting practices using evidence from Uganda. This is done through a questionnaire survey of Chief Finance Officers and Internal audit managers of financial services firms in Uganda. Of the 62 financial services firms in Uganda considered for this study, useable responses were received from 48 firms. The composition of 48 financial services firms is 22 commercial banks, 23 insurance firms (both life and nonlife assurance) and three micro deposit taking institutions. The study finds that both ACE and IAF have a positive and significant association with sustainability reporting practices in Uganda.

The reminder of the paper is structured as follows. The succeeding section discusses the literature review, and this is followed by methodology. The penultimate section is results and lastly, discussion and concluding remarks.
Sustainability reporting practices 
AJAR

7,2

166

\section{Literature review}

\subsection{Theoretical foundation}

We employ the agency and legitimacy theories in explaining the association between ACE, IAF and sustainability reporting practices. The agency theory as proposed by Jensen and Meckling (1976) assumes that human beings have selfish interests, and there are bound to be conflicts between resource providers and managers. The resource providers appoint the board to monitor the actions of management. The board of directors minimizes agency problems through putting in place internal monitoring mechanisms such as the audit committees and the IAF. The audit committees and the IAF are expected to monitor closely the activities of management. This is done through promotion of improved reporting practices such as sustainability reporting practices. With the improved sustainability reporting practices, accountability for all the resources entrusted to the managers is fully achieved. This resonates Bananuka et al. (2018), who suggested that for proper accountability, there must be an effective audit committee and a functioning internal audit.

The foundation of the agency theory is shareholders' wealth maximization and as such, managers are expected to make sufficient disclosures to the satisfaction of the shareholders. The financial institutions have a number of stakeholders such as clients, regulators, civil society organizations, among others, whose expectations go beyond those of the shareholders. Where the activities of an organization do not meet the expectations of the society in which it operates, then there is a legitimacy gap (Guthrie et al., 2007), and this must always be closed by those charged with governance such as the board audit committee.

Legitimacy is described by Suchman (1995) as a generalized assumption that the organization's actions are desirable and appropriate within some socially constructed system of norms, values, beliefs and definitions. Legitimacy theory assumes that organizations continually seek to ensure that they operate within the bounds and norms of their respective societies. Organizations voluntarily report on their overall activities if management considers those activities to be expected by the communities in which they operate (Guthrie et al., 2007). This can be made possible if there are effective audit committees and functioning internal audit departments. Firms with effective audit committees and IAF are likely to prepare sustainability reports that are unbiased. Firms whose audit committees and IAF are not sensitive to the demands of the general society are more likely not to prepare sustainability reports. The audit committees and the IAF need to ensure that firms prepare sustainability reports where the contents of such reports are traceable or can be verified. The Financial Institutions Act of 2004 requires every financial institution to have an audit committee and an internal auditor who work together to ensure that the information disclosed by the financial institution is generated by a reliable accounting and computer system. Therefore, both the audit committee and the internal audit have a responsibility of ensuring that information disclosed in the sustainability report is relevant and reliable. Otherwise, if management does not report on all aspects of the entity operations, society may revoke its implicit license.

\subsection{Hypothesis development}

2.2.1 Audit committee effectiveness and sustainability reporting practices. Beasley et al. (2009) describes the audit committee as a unit established amongst board of directors to monitor and ensure accuracy in company disclosures. The audit committee is expected to review all the information contained in the entity's reports, especially those for external use. Such reports include sustainability reports. In reviewing the nonfinancial information, sustainability information is reviewed, and if such information is not included, the audit committee may recommend so to the entire board. Because the audit committee is a technical committee of the board on audit and reporting issues, its recommendations for adoption of better or enhanced reporting practices such as sustainability reporting practices are given an upper hand. The 
focus of an effective audit committee has shifted from overseeing the traditional financial reporting to dealing with emerging developments in reporting such as sustainability and integrated reporting. There are two strands in the literature on the attributes of ACE. The first strand views the effectiveness of audit committee based on their characteristics such as independence, size, financial expertise, authority and diligence/frequency of meetings (Bually and Al-Ajmi, 2019; Haji and Anifowose, 2016; Bananuka et al., 2019). Other scholars consider an effective audit committee as that committee which executes its responsibilities of reviewing corporate financial information, supervising the internal audit systems and liaising with external auditors (Lin et al., 2008; Bananuka et al., 2018).

Studies on the association between ACE and sustainability reporting practices using evidence from financial services firms in developing countries are few except for Bually and Al-Ajmi (2019). Bually and Al-Ajmi (2019) found that audit committee independence and meetings were positively significant, while financial expertise was negatively related to the extent of sustainability reporting among banks in the Gulf Cooperation Council countries. Further, Samaha et al. (2015) found that the audit committee has a positive and significant impact on voluntary disclosures. Also, Haji and Anifowose (2016) conducted a study on audit committee and integrated reporting practice and found that the audit committee function is strongly and positively associated with integrated reporting. Agyei-Mensah (2019) indicated that ACE has a positive and significant impact on corporate voluntary disclosure quality using evidence from Ghana. Bananuka et al. (2018) noted that ACE significantly contributes to accountability. This means that audit committee in executing their role of reviewing financial and nonfinancial information, supervising internal audit systems/function and liaising with external auditors improves the reporting practices of the financial institution. Because banks are seen as the financiers of other companies such as manufacturing firms whose activities have a direct negative impact on the natural environment and society, it is incumbent upon the audit committees of such institutions to ensure that the respective financial services firms disclose all their environmental, social and economic performances to their stakeholders. By promoting such disclosures, their clients (manufacturing firms and other companies) are likely to adopt similar practices. The audit committees may also initiate and influence the board of directors to pass decisions aimed at improving the respective financial institution's reporting practices and including in the requirements for companies to access financing from such entities a sustainability report. Our argument is such that financial institutions that have an effective audit committee are likely to have improved practices of sustainability reporting. The following hypothesis is thus stated:

H1. Audit committee effectiveness is positively associated with sustainability reporting practices

2.2.2 Internal audit function and sustainability reporting practices. The agency theory requires that an internal audit is in place to minimize agency problems. This fact is recognized in the Uganda's Financial Institutions Act (2004), which requires financial institutions to have in place a functioning internal audit that evaluates the reliability of the information produced by accounting and computer systems, provide an independent appraisal function, evaluate the effectiveness, efficiency and economy of operations, evaluate compliance with laws, policies and operating instructions, provide investigative services to line management and also certify returns submitted to the Central Bank by the financial institution. The International Auditing and Assurance Standards Board (IAASB) (2013) describes an IAF as a function in an organization which performs assurance and consulting activities designed to evaluate and improve the effectiveness of risk management, internal controls and governance processes of an entity. It is understood as a function in the organization responsible for reviewing and evaluating the effectiveness of internal control systems, risk management and regulatory compliance (Bananuka et al., 2018). 
AJAR

7,2

168

With the current increase in demand for reporting on the entity's nonfinancial information, the role of the IAF involves providing assurance on the ESG (economic, social and governance) issues (Dominic and Martinov-Bennie, 2015). The IAF, especially of financial services firms, can improve sustainability reporting practices through the various recommendations to management as a way of contributing to risk management. At any one time, stakeholders may look at banks as culprits of environmental conservation and possibly, hold them responsible for society suffering. This is because banks have the capacity to require all their clients to produce sustainability reports. At this point, the IAF advises management to require their clients to prepare sustainability reports if they are to access any form of financing. Because, there are more disclosures in a sustainability report if prepared based on GRI, the banks can have access to more information about the organization than basing on merely financial statements. Studies that link IAF to sustainability reporting practices are uncommon. However, there are studies that document positive and significant associations with integrated reporting (e.g. Engelbrecht et al., 2018) and accountability (e.g. Bananuka et al., 2018). The IAF is responsible for evaluating and improving risk management, internal controls and compliance with applicable laws such as the Uganda Environmental Act of 2019. This means that firms with the IAF are able to evaluate the potential risks involved with not providing a report on economic, social and environmental activities of a firm. The IAF also evaluates the reliability of corporate reports produced by the accounting systems and thus can analyze and suggest information to be included in the corporate sustainability reports. We therefore hypothesize that:

H2. Internal audit function is positively associated with sustainability reporting practices.

\section{Materials and methods}

This study utilized a cross sectional and correlational research design. The study population was 62 financial services firms. Useable questionnaires were received from 48 financial services firms representing a response rate of $77 \%$. The 48 financial services are the commercial banks, insurance firms and micro deposit taking institutions (22 commercial banks, 23 insurance firms (both life and nonlife assurance) and three micro deposit taking institutions). These form the core of the financial service industry in Uganda. The other financial services firms are the savings and credit cooperative societies and the foreign exchange bureaus which largely are categorized in the small and medium enterprises and were not considered for this study. Data collection started in June 2018 and ended in December 2019. Responses were enlisted from both the Chief Finance Officers (CFO) and the internal audit manager of the financial services firms. The CFOs were selected because they are in charge of corporate reporting of a firm and they are knowledgeable in terms of firm operations. The CFOs are the preparers of sustainability reports. Internal auditors are aware of whatever takes place in the entity since they are responsible for evaluating the internal controls, contributing to risk management processes and ensuring compliance with all the existing laws. Section 59 sub-section $6 \mathrm{a}$ and $\mathrm{b}$ of the Uganda's financial institutions' Act of 2004 requires all the officers responsible for internal audit and the officers in charge of financial and treasury functions of an institution to attend all the meetings of the audit committee. As such, this study believes that the CFO and the head of the IAF have vast knowledge on the operations of the audit committees and can thus ably evaluate them on their effectiveness. Thereafter, the $\mathrm{CFO}$ and internal audit manager responses were aggregated to minimize bias on either side. The sample characteristics results are presented in Table 1.

We utilized a six-point Likert scale questionnaire ranging from completely disagree to completely agree with closed-ended questions. The questionnaire was designed on the basis of measurement scales from earlier research after a thorough review of the literature on IAF, 


\begin{tabular}{|c|c|c|c|c|}
\hline \multicolumn{2}{|l|}{ Background information } & \multirow{2}{*}{$\frac{\text { Frequency }}{41}$} & \multirow{2}{*}{$\frac{\text { Percentage }}{66.1}$} & \multirow{2}{*}{$\begin{array}{r}\text { Sustainability } \\
\text { reporting } \\
\text { practices }\end{array}$} \\
\hline Gender & Male & & & \\
\hline & Female & 21 & 33.9 & \\
\hline & Total & 62 & 100 & \\
\hline \multirow[t]{3}{*}{ Age } & Less than 30 years & 13 & 21.0 & \\
\hline & 30 years and above & 49 & 79.0 & \\
\hline & Total & 62 & 100 & 169 \\
\hline \multirow[t]{6}{*}{ Education } & Diploma & 1 & 1.6 & \\
\hline & Bachelor's degree & 41 & 66.1 & \\
\hline & Master's degree & 16 & 25.8 & \\
\hline & $\mathrm{PhD}$ & 1 & 1.6 & \\
\hline & Others & 3 & 4.8 & \\
\hline & Total & 62 & 100 & \\
\hline \multirow[t]{4}{*}{ Professional qualification } & $\mathrm{CPA}$ & 35 & 56.5 & \\
\hline & ACCA & 21 & 33.9 & \\
\hline & Others & 6 & 9.6 & \\
\hline & Total & 62 & 100 & \\
\hline \multirow[t]{5}{*}{ Length of service } & Less than 5 years & 23 & 37.1 & \\
\hline & $5-10$ years & 26 & 41.9 & \\
\hline & $10-15$ years & 10 & 16.1 & \\
\hline & 15 years and above & 3 & 4.8 & \\
\hline & Total & 62 & 100 & Table 1. \\
\hline Source(s): Primary data & & & & Respondent profile \\
\hline
\end{tabular}

ACE and sustainability reporting. We then tested for the content validity of the measurement scales by giving it to four academicians and four practitioners, and their comments were incorporated in revising the questionnaire before presenting it to the respondents. We further tested the reliability of the instrument to find out if it consistently measured the study variables. Reliability (internal consistency and stability) of the instruments was tested using Cronbach's alpha coefficient (Cronbach, 1951). The Cronbach's alpha coefficients for the study variables were as follows: ACE (0.958) and IAF (0.927). The instrument used for this study was reliable given that all the Cronbach's $\alpha$ coefficients were above 0.7 as recommended by Cronbach (1951).

We conducted factor analysis to reduce data into a manageable size as suggested by Field (2009). We suppressed all factors with loadings below 0.5 coefficients to eliminate factors with weak loadings. The principal components for each variable were extracted by running principal component analysis using varimax rotation method. We extracted the KaiserMeyer-Olkin (KMO) and Bartlett tests of sphericity to assess the reliability of the measures. The KMO values for ACE, and IAF were 0.905 and 0.848 , respectively. According to Field (2009), the KMO values of 0.5 and above are acceptable. The Bartlett tests of sphericity were all statistically significant $(\phi>0.000)$ and the approximate chi square were as follows: ACE $\left(\chi^{2}=1399.118\right)$ and IAF $\left(\chi^{2}=2287.159\right)$.

The dependent variable for this study is sustainability reporting practices which was operationalized based on the GRI indicators (economic, social and environmental indicators). This study followed the GRI standards 2016 as the disclosure index specifically the comprehensive option for preparing sustainability reports. We opted for the comprehensive option to gauge the extent of compliance on the aspects of the GRI 2016 standards by financial services firms in Uganda. If an item from the GRI standards 2016 is disclosed in an annual or sustainability or integrated report, a weight of 1 was given and if not, weight of 0 was given. After scoring, a percentage level of disclosure on any performance indicator was computed, where number of items disclosed were divided by the total number of required 
AJAR

7,2

170

disclosures. After obtaining the percentage level of disclosures on a given indicator, the percentage was put on a Likert scale of $1-6$ to match the scale of the predictor variables. In this case $0-16.7 \%=1 ; 16.8 \%-33.4 \%=2 ; 33.5 \%-50.1 \%=3 ; 50.2 \%-66.8 \%=4 ; 66.9 \%-$ $83.5=5$ and $83.4 \%-100 \%=6$. This method has previously been used by accounting scholars such as Nalukenge et al. (2018).

The measurement of the independent variables is indicated in Table 2. ACE was measured based on the works of (Lin et al., 2008; Bananuka et al., 2018) as review of corporate sustainability information, supervision of internal audit systems and liaison with external auditors. However, supervision of internal audit systems loaded together with review of sustainability information where 10 factors loaded (see Table A1). Also, five factors loaded on to liaison with external auditors. IAF was measured in terms of review and evaluation of the effectiveness of internal control systems, risk management and regulatory compliance (Bananuka et al., 2018). On factor analysis, items on regulatory compliance and risk management loaded on together. We finally document that IAF in financial services firms is a function of review and evaluation of internal control systems and risk management practices. Factor analysis results are presented in Table A1 and A2.

According to Bartov et al. (2000) when confounding variables are not controlled for, the hypothesis which would have been accepted may be rejected and thus showing false results. To remove the possibility of bias in our results, we controlled for the effect of firm age, firm size and auditor type in examining the association between ACE and IAF on sustainability reporting practices. Firm age and size have been previously found to be positively and significantly associated with sustainability disclosures (see Shamil et al., 2014; Orazalin and Mahmood, 2018). Orazalin and Mahmood (2018) also found that auditor type is positively

\begin{tabular}{|c|c|c|}
\hline Variable & Acronym & Variable description \\
\hline \multicolumn{3}{|l|}{ Dependent variable } \\
\hline $\begin{array}{l}\text { Sustainability reporting } \\
\text { practices }\end{array}$ & $\mathrm{SRP}$ & $\begin{array}{l}\text { Measured based on the GRI standards } 2016 \text { on environmental, social } \\
\text { and economic indicators }\end{array}$ \\
\hline \multicolumn{3}{|l|}{ Predictor variable } \\
\hline $\begin{array}{l}\text { Audit committee } \\
\text { effectiveness }\end{array}$ & $\mathrm{ACE}$ & $\begin{array}{l}\text { Measured by average score of questions on a six-point Likert scale on } \\
\text { review of financial and nonfinancial information and liaison with } \\
\text { external auditors }\end{array}$ \\
\hline Internal audit function & IAF & $\begin{array}{l}\text { Measured by average score of questions on a six-point Likert scale on } \\
\text { review and evaluation of internal control systems and risk } \\
\text { management }\end{array}$ \\
\hline \multicolumn{3}{|l|}{ Control variables } \\
\hline Firm age & AGE & $\begin{array}{l}\text { A dummy variable coded as } 0 \text { if the firm has been in operation for at } \\
\text { least five years, } 1 \text { if the firm has been in operation for above five years } \\
\text { but not more than } 10 \text { years, } 2 \text { if the firm has been in operation for } \\
\text { more than } 10 \text { years but not more than } 15 \text { years and } 3 \text { if the firm has } \\
\text { been in operation for more than } 15 \text { years }\end{array}$ \\
\hline Firm size & SIZE & $\begin{array}{l}\text { A dummy variable coded as } 0 \text { if the firm employs } 50 \text { and below } \\
\text { employees and, } 1 \text { if the firm employs more than } 50 \text { employees }\end{array}$ \\
\hline \multirow[t]{3}{*}{ Auditor type } & AUD & $\begin{array}{l}\text { A dummy variable coded as } 0 \text { if the firm is audited by the big } 4 \text { audit } \\
\text { firms [such as PwC, Ernst and Young, KPMG, Delloite and Touche], } 1 \\
\text { if the firm is audited by the small and medium audit practices [such } \\
\text { as Sejjaaka Kaawaase and company certified public accountants] } \\
\text { and } 2 \text { if the firm is always audited by both the big } 4 \text { audit firms and } \\
\text { the small and medium audit practices }\end{array}$ \\
\hline & $\beta_{0}$ & Constant \\
\hline & Ej & Error term \\
\hline
\end{tabular}

Table 2.

Measurement of variables 
related to sustainability disclosures. We also introduce control variables into our model because, failure to consider for endogeneity can lead to biased and inaccurate results hence the risk of drawing incorrect conclusions about the effect of the hypothesized relationships (Zaefarian et al., 2017).

According to Kennedy (2008), endogeneity problems occur if the independent variable highly correlates with the structural error term. In our correlation analysis results (see Table 4), there are no high correlations between the predictor variables and the outcome variables. We also run the Durbin Watson test to check whether there are any serial correlations among the independent variables and the standard errors. We find that there are no serial correlations. The Durbin Watson test results are presented in Table 5. Prior to further analyses, we checked for missing data because data unavailability may also lead to endogeinity challenges.

We utilized a multiple regression model to examine the association between ACE, IAF and sustainability reporting practices. We run the following regression models:

$$
\begin{array}{ll}
\text { Model 1: } & \mathrm{SRP}=\beta_{0}+\beta_{1} \mathrm{SIZE}+\beta_{2} \mathrm{AGE}+\beta_{3} \mathrm{AUD}+\varepsilon_{j} \\
\text { Model 2: } & \mathrm{SRP}=\beta_{0}+\beta_{1} \mathrm{SIZE}+\beta_{2} \mathrm{AGE}+\beta_{3} \mathrm{AUD}+\beta_{4} \mathrm{ACE}+\varepsilon_{j} \\
\text { Model 3: } & \mathrm{SRP}=\beta_{0}+\beta_{1} \mathrm{SIZE}+\beta_{2} \mathrm{AGE}+\beta_{3} \mathrm{AUD}+\beta_{4} \mathrm{IAF}+\varepsilon_{j} \\
\text { Model 4: } & \mathrm{SRP}=\beta_{0}+\beta_{1} \mathrm{SIZE}+\beta_{2} \mathrm{AGE}+\beta_{3} \mathrm{AUD}+\beta_{4} \mathrm{ACE}+\beta_{5} \mathrm{IAF}+\varepsilon_{j}
\end{array}
$$

where SRP is sustainability reporting practices, ACE is audit committee effectiveness, IAF is Internal audit function, AGE is firm age, SIZE is firm size, AUDT is auditor type, $\beta_{O}$ is a constant and $\varepsilon_{j}$ is the error term.

\section{Results}

\subsection{Descriptive statistics}

We performed descriptive statistics for the study variables. Table 3 presents the descriptive statistics indicating the means and standard deviations of the study variables. The means represent the summary of the data, while the standard deviation shows the extent to which the means represent the data (Field, 2009). The mean and standard deviation scores for

\begin{tabular}{|c|c|c|c|c|c|c|c|c|c|}
\hline Variable & $N$ & $\begin{array}{c}\text { Min } \\
\text { Statistic }\end{array}$ & $\begin{array}{c}\text { Max } \\
\text { Statistic }\end{array}$ & $\begin{array}{c}\text { Mean } \\
\text { Statistic }\end{array}$ & $\begin{array}{c}\text { Std. } \\
\text { Deviation } \\
\text { Statistic }\end{array}$ & $\begin{array}{r}\text { Ske } \\
\text { Statistic }\end{array}$ & $\begin{array}{l}\text { ess } \\
\text { Std. } \\
\text { Error }\end{array}$ & Statistic & $\begin{array}{l}\text { sis } \\
\text { Std. } \\
\text { Error }\end{array}$ \\
\hline SRP & 48 & 1.56 & 5.51 & 3.85 & 0.91 & -0.52 & 0.34 & -1.03 & 0.67 \\
\hline ENI & 48 & 2.39 & 6.00 & 4.57 & 1.00 & -0.76 & 0.34 & -0.41 & 0.67 \\
\hline SOI & 48 & 1.00 & 5.53 & 3.57 & 0.86 & -0.60 & 0.34 & -1.06 & 0.67 \\
\hline ECI & 48 & 1.00 & 5.60 & 3.42 & 0.88 & -0.38 & 0.34 & -1.16 & 0.67 \\
\hline IAF & 48 & 1.00 & 6.00 & 4.09 & 0.43 & -1.01 & 0.34 & -0.25 & 0.67 \\
\hline RIC & 48 & 1.00 & 6.00 & 4.48 & 0.53 & -1.18 & 0.34 & 0.01 & 0.67 \\
\hline RIM & 48 & 1.00 & 6.00 & 3.69 & 0.58 & -0.49 & 0.34 & -1.27 & 0.67 \\
\hline ACE & 48 & 1.00 & 5.80 & 4.17 & 0.62 & -1.06 & 0.34 & -0.42 & 0.67 \\
\hline RSI & 48 & 1.00 & 5.80 & 4.37 & 0.57 & -1.32 & 0.34 & 0.31 & 0.67 \\
\hline LEX & 48 & 1.00 & 6.00 & 3.98 & 0.76 & -0.81 & 0.34 & -0.95 & 0.67 \\
\hline SIZE & 48 & 0.00 & 1.00 & 0.80 & 0.75 & 0.20 & 0.34 & 0.41 & 0.67 \\
\hline AGE & 48 & 0.00 & 3.00 & 1.84 & 1.21 & -0.53 & 0.34 & -1.33 & 0.67 \\
\hline AUD & 48 & 0.00 & 2.00 & 0.38 & 0.61 & 1.40 & 0.34 & 1.00 & 0.67 \\
\hline
\end{tabular}
sustainability reporting practices, ACE and IAF are 3.85 and 0.91, 4.09 and 0.43, 4.17 and 0.62, respectively. On a Likert scale of $1-6$, financial services firms agree that they disclose items of the GRI 2016 standards up to $64 \%((3.85 / 6) * 100 \%)$. For the control variables, the means and

Note(s): ENI: Environmental indicators; SOI: Social indicators; ECI: Economic indicators Source(s): Primary data
Sustainability reporting practices 
\begin{tabular}{l} 
AJAR \\
7,2 \\
$\mathbf{1 7 2}$ \\
\hline
\end{tabular}

Table 4.

Correlation analysis results

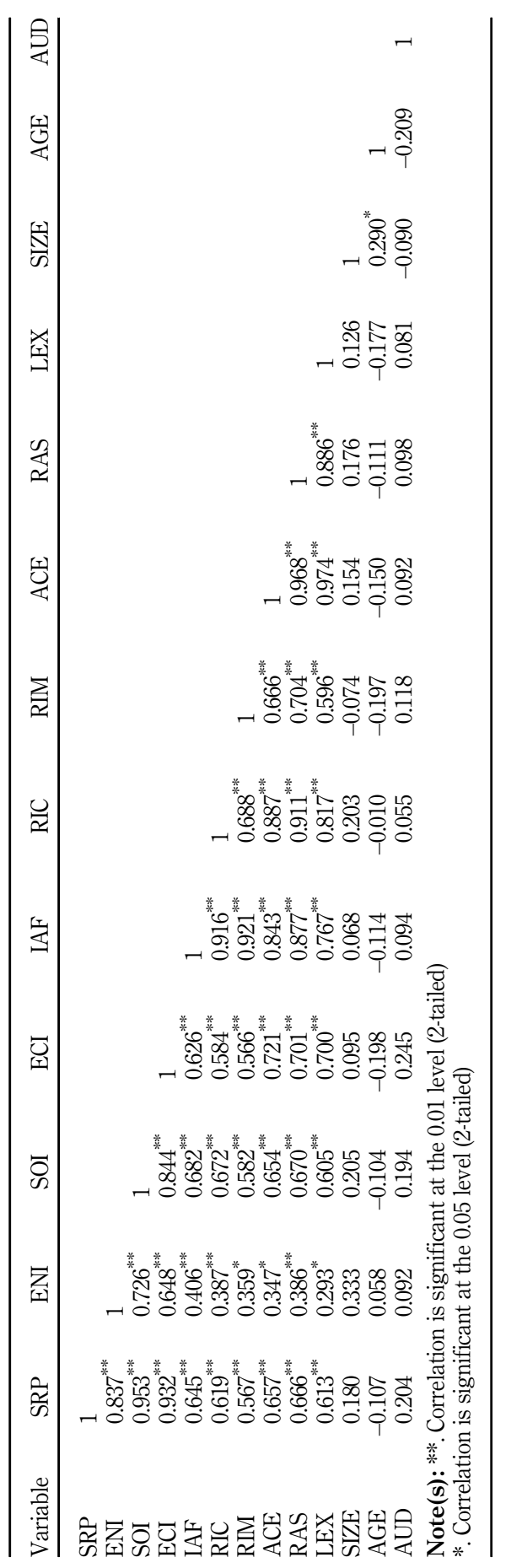




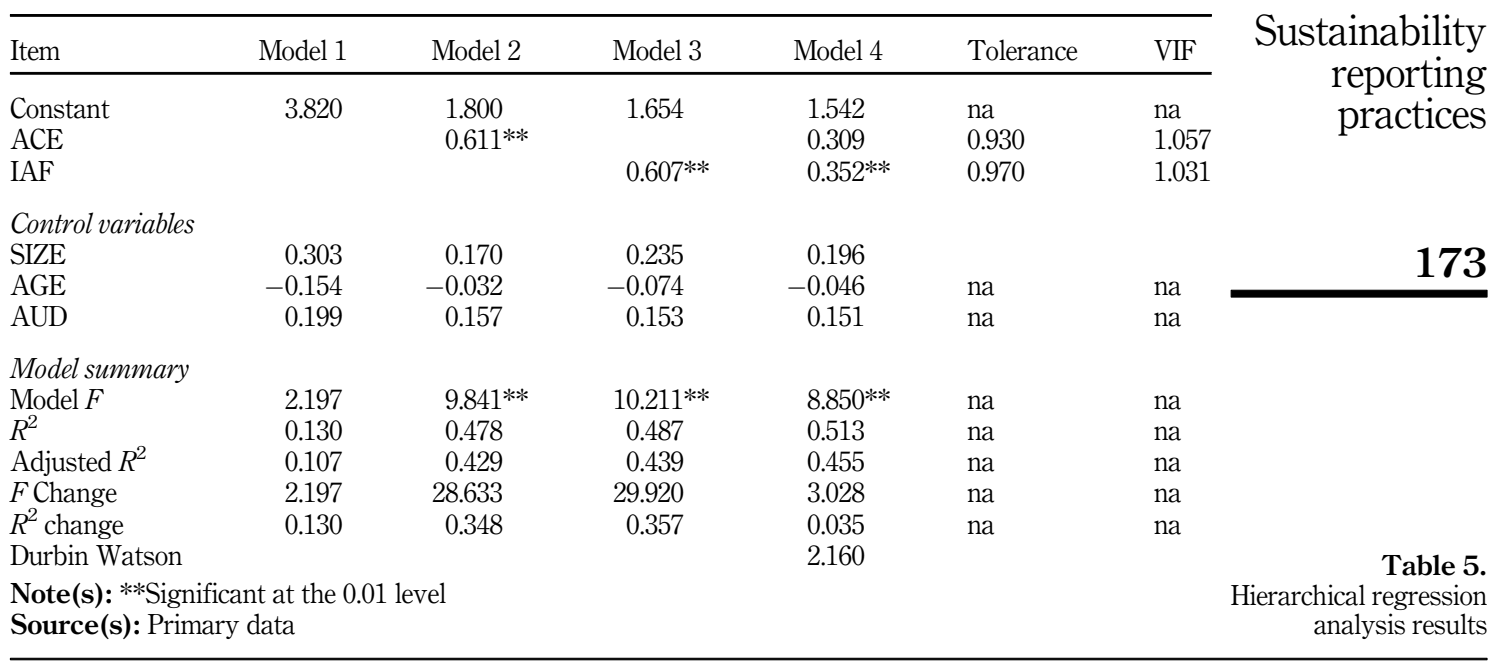

standard deviation for firm size, firm age and auditor type were 0.80 and $0.75,1.84$ and 1.21, and 0.38 and 0.61 , respectively.

We also checked for normality of the data. We ran skewness and kurtosis and found that all values are within the range of -3.29 to 3.29 as recommended by Field (2009). This means that our data was normal. We checked for the normality of the data because the Pearson correlation requires data that is normal (Field, 2009).

\subsection{Correlation results}

We ran a Pearson correlation analysis to establish the association between IAF, ACE and sustainability reporting practices as represented in Table 4. Results indicate that there is a positive and significant correlation between IAF and sustainability reporting practices $\left(r=0.645^{* *}, p<0.01\right)$, and this means that a positive change in IAF brings about a positive change in the sustainability reporting practices. Results further indicate a positive and significant correlation between ACE and sustainability reporting practices $(r=0.657 * *$, $p<0.01)$, meaning that a positive change in the effectiveness of audit committee will lead to a positive change in sustainability reporting practices. We found no significant associations between the firm age, firm size, auditor type and sustainability reporting practices. This is an indication that the associations between IAF, ACE and sustainability reporting practices are not affected by the control variables.

\subsection{Hierarchical regressions}

To examine the association between ACE, IAF and sustainability reporting practices, we run a hierarchical regression analysis which is presented in Table 5. The hierarchical regression analysis enables the research to establish the extent of the association of each independent variable in the model and the dependent variable (Field, 2009). The hierarchical regression analysis also show the incremental explanatory power of each independent variable added on the already existing variable in the model (Field, 2009). In model 1, we enter the control variables which are firm size, firm age and auditor type to examine their association with sustainability reporting, and the results indicate no significant association. This is consistent with the correlation analysis results. This means that the control variables do not explain any significant variance in sustainability reporting practices, and therefore, our models are highly credible 
AJAR

7,2

174

since they are not sensitive to the confounding variables. However, among the control variables, firm size has a higher standardized beta as compared to other control variables. In model 2, we examine the association between ACE and sustainability reporting practices. Results indicate that ACE (standardized $\beta=0.611$ ) significantly predicts sustainability reporting practices. Model 2 explains $42.9 \%$ (Adjusted $R^{2}=0.429$ ) of the variance in sustainability reporting practices. In model 3, we test the extent of the association of IAF with sustainability reporting practices. We found that IAF significantly associates with sustainability reporting practices. IAF contributes $43.9 \%$ to variances in sustainability reporting practices. In model 2 and 3 , we test ACE and IAF separately to reduce the endogeinity problem. We also include control variables which further reduce the endogeinity problem. In model 4 , we combine both ACE and $\mathrm{IAF}$ and find that $\mathrm{ACE}$ ceases to be a significant predictor, while IAF (standardized $\beta=0.352$ ) remains a significant predictor. Model 4 which is our final model predicts $45.5 \%$ of the variance in sustainability reporting practices.

In addition to the above analyses, we performed further analyses. Given that we found a significant association between ACE and IAF to sustainability reporting practices, we further tested among the sustainability reporting indicators, which one is highly linked to either ACE or IAF. These results are presented in Tables 6 and 7. We found that audit committees

\begin{tabular}{lccc}
\hline Item & Environmental indicators & Social indicators & Economic indicators \\
\hline Constant & 3.478 & 1.074 & 0.849 \\
ACE & $0.323^{* *}$ & $0.615^{* *}$ & $0.655^{* *}$ \\
Control variables & & & \\
SIZE & 0.171 & 0.146 & 0.155 \\
AGE & 0.076 & -0.024 & -0.107 \\
AUD & 0.093 & 0.146 & 0.175 \\
Model summary & & & \\
Model F & 2.125 & 9.364 & 14.615 \\
$R^{2}$ & 0.165 & 0.466 & 0.576 \\
Adjusted $R^{2}$ & 0.087 & 0.416 & 0.537 \\
Durbin Watson & 2.021 & 2.091 & \\
Note(s): **Significant at the 0.01 level & & \\
Source(s): Primary data & & & \\
\end{tabular}

Table 6.

Regression results of audit committee effectiveness and sustainability indicators

\begin{tabular}{lccc}
\hline Item & Environmental indicators & Social indicators & Economic indicators \\
\hline Constant & 3.202 & 0.732 & 1.027 \\
IAF & $0.392^{* *}$ & $0.648^{* *}$ & $0.575^{* *}$ \\
Control variables & & & \\
SIZE & 0.197 & 0.207 & 0.235 \\
AGE & -0.063 & -0.061 & -0.164 \\
AUD & 0.085 & 0.139 & 0.177 \\
Model summary & & & \\
Model F & 2.975 & 11.678 & 10.127 \\
$R^{2}$ & 0.217 & 0.521 & 0.485 \\
Adjusted $R^{2}$ & 0.144 & 0.476 & 0.437 \\
Durbin Watson & 2.104 & 2.141 & \\
Note(s): **Significant at the 0.01 level & & \\
Source(s): Primary data & & & \\
\end{tabular}

Table 7.

Regression results of Internal audit function and sustainability indicators 
effectiveness is more linked to social and economic indicators as compared to environmental indicators. We also found that IAF is more linked to social and economic indicators as compared to environmental indicators.

We tested for multicolinearity among our study variables and found that there were nonexistent since our tolerance values were above 0.2 while variance inflation factors were all below 10 as recommended by Field (2009). We further obtained the Durbin Watson values which were within 2 as recommended by Field (2009) to indicate that there were no serial correlations.

\section{Sustainability reporting practices}

\section{Discussion}

The present study results provide evidence on the association between IAF, ACE and sustainability reporting practices in financial services firms using evidence from a developing African country - Uganda. Both IAF and ACE contribute to positive variances in sustainability reporting practices. The association of ACE to sustainability reporting practices becomes insignificant in the presence of an IAF. This implies that the explanatory power of ACE is subsumed in IAF. Based on the Uganda's Financial Institutions Act of 2004, the IAF performs among other duties the role of giving an assurance on risk management and making recommendations on how best to manage the risks. In so doing, the internal audit may make recommendations on managing risks, and one such recommendation is adoption of sustainability reporting practices.

In performing their roles, internal auditors report to the audit committee of the board. In the normal performance of internal audit roles, any challenges faced especially in regard to failure of management to implement internal auditor's recommendations may be reported to the audit committees which in turn sanctions management to respond to such recommendations. The audit committee is a committee of the board, and thus, those internal audit recommendations that are strategic in nature are presented in the board for appropriate decisions. The board may thus direct that the firm prepares sustainability report, especially if it has been viewed as one of the sources of risk. In Uganda, there are financial services firms that are listed on the Uganda Securities Exchange, and this increases on the need for more information provision. In addition, financial services firms in Uganda are required to publish their performance in a suitable media. This means that financial services firms that prepare one stop report that entails the economic, social and environmental performance are more less burdened by the various information needs of regulators such Bank of Uganda (Regulator for banks and deposit taking institutions), Insurance Regulatory Authority (regulator for insurance firms), National Environmental Management Authority and the Capital Markets Authority. In addition to the regulatory authorities, there are investors who may also have other information needs as provided for in the agency and stakeholder theories.

We notice the high correlations between ACE and IAF. This is likely because the duties/ roles of the ACE and IAF are complementary. There is therefore close link between the two, especially in the Ugandan context. Further, the audit committees link the IAF to the board which makes strategic decisions such as sustainability reporting practices. If this is the case, it means that behind a strong audit committee, there is a board. We also argue that large-sized organizations are more likely to attract quality members of the audit committees and the staff in the IAF than small-sized firms. This is evidenced by the high standardized beta of 0.303 for firm size. Previous studies such as Shamil et al. (2014) document that firm size is the core determinant of sustainability disclosures.

Our study findings confirm to the clause in the King IV report of corporate governance which specifies that an audit committee oversees the work of the IAF. In Uganda, the Financial Institutions Act (2004) requires the audit committee to review the internal controls, 
AJAR

7,2

operating procedures, systems and management information systems of the financial institution and review the internal audit report and programs of the financial institution. This explains that in an organization, where the audit committee is very effective, it incorporates the IAF. The present study results are in compliance with the findings of Agyei-Mensah (2019), who found that ACE has a positive significant association with the quality of corporate voluntary disclosures. Our results are also in line with the findings of Haji and Anifowose (2016), whose findings indicated that effectiveness of the audit committee is a significant factor in explaining integrated reporting.

The study results are in agreement with those of Bananuka et al. (2018), who investigated the relationship between IAF and ACE with accountability in the Ugandan statutory corporations and found that ACE is not significant for accountability in statutory corporations where internal audit is present in such corporations. From Bananuka et al. (2018), the IAF is more critical for improving accountability in the public sector as compared to the audit committees. This can be explained by the emphasis put on the internal audit than the audit committee. In the Uganda's public sector, the internal auditor is functionally supervised by the internal auditor general, who is appointed by the Uganda's ministry of public service, while the internal auditors in the statutory corporations are appointed by the respective board audit committees. The board audit committees in those statutory corporations are also supervised by the internal auditor general. In the presence of such regulations, this study confirms that the IAF is critical for improving sustainability reporting practices.

ACE is better observed through reviews of sustainability information and liaison with the institution's external auditors. The results are in line with the views of Lin et al. (2008), who documented that audit committees promote good practices of corporate governance through coordinating internal and external auditors. In reviewing corporate financial information, the audit committee effectively executes the responsibility of monitoring the corporate reporting process as noted by Lin et al. (2008) and ensures accuracy of both financial and nonfinancial disclosures (Beasley et al., 2009; Samaha et al., 2015). We also noted that supervision of internal audit systems does not determine the effectiveness of audit committees in financial institutions in Uganda, which was also noted by Bananuka et al. (2018) using evidence of Ugandan statutory corporations.

IAF is better observed through their responsibility of reviewing the internal control system and contribution to risk management processes. This present study noted that regulatory compliance does not explain the IAF in Ugandan financial service firms. For sustainability reporting practices, it is very crucial for the Ugandan financial institutions to have in place proper internal control systems that are regularly reviewed by the internal auditors. Our results are in support with Engelbrecht et al. (2018), who noted that internal audit is equipped with comprehensive knowledge and has a wider view of the entity which enables them to design the most appropriate processes and controls ensuring accuracy and validity of an integrated report. In reviewing the effectiveness of internal controls and contribution to risk management, internal auditors makes recommendations on how to improve reporting practices. Given that sustainability reporting is still voluntary in Uganda, the recommendations of the internal audit in an organization, especially in the area of management of risks related to legitimacy are more likely to be taken on.

\section{Concluding remarks}

This paper examined the association between ACE, IAF and sustainability reporting practices using evidence from Uganda's financial services firms. After controlling for firm age, firm size and auditor type, we found that both ACE and IAF to be independently significantly associated with sustainability reporting practices. We further found that IAF is positively and significantly associated with sustainability reporting practices with or without 
the ACE. The study finds that ACE is positively and significantly associated with sustainability reporting practices in the absence of an IAF.

This study has important contributions. The study fills a gap in the extant literature on the association between $\mathrm{ACE}$, IAF and sustainability reporting practices using evidence from an African developing country. The findings support the agency theory and legitimacy theory, suggesting that an effective audit committee and IAF enhance corporate reporting practices. With respect to policy makers, results highlight that ACE enhance sustainability reporting practices, and hence, they should encourage board of financial institutions to insist on audit committees that have people with financial and sustainability expertise to review the corporate financial and other nonfinancial information, advise on application of accounting policies and meeting regularly with their external auditors to ensure disclosure of sustainability information. With respect to managers, findings from the study emphasize the importance of an effective audit committee that monitors the IAF in particular reviewing the internal audit report/programs of the financial institution and holding meetings that coordinate the internal and external auditors.

Like any other study, this study has limitations, and we urge readers of this paper to interpret our results with caution. Our study only focuses on financial services firms, which is a small sample. Future studies may be conducted in other sectors or other national settings with large samples. We also note that our independent variables only predict about $45.5 \%$. Also, the conceptualization of ACE only focuses on the role performance aspect of the audit committees and therefore, does not consider the ACE as proxied by audit committee independence, size, diligence and frequency of meetings which warrants further studies. Future research may also consider replicating or expanding this study in other settings while including more variables. In the presence of the above study limitations, we believe that this study results provide an initial empirical evidence on the association between IAF, ACE and sustainability reporting practices using evidence from an African developing country.

\section{References}

Agyei-Mensah, B.K. (2019), "The effect of audit committee effectiveness and audit quality on corporate voluntary disclosure quality", African Journal of Economic and Management Studies, Vol. 10 No. 1, pp. 17-31.

Amidjaya, P.G. and Widagdo, A.K. (2019), "Sustainability reporting in Indonesian listed banks. Do corporate governance, ownership structure and digital banking matter?", Journal of Applied Accounting Research, Vol. 21 No. 2, pp. 231-247.

Amran, A., Lee, S.P. and Devi, S.S. (2014), "The influence of governance structure and strategic corporate social responsibility toward sustainability reporting quality", Business Strategy and the Environment, Vol. 23 No. 4, pp. 217-235.

Bananuka, J., Nkundabanyanga, S.K., Nalukenge, I. and Kaawaase, T. (2018), "Internal audit function, audit committee effectiveness and accountability in the Ugandan statutory corporations", Journal of Financial Reporting and Accounting, Vol. 16 No. 1, pp. 138-157.

Bananuka, J., Walugyo, A.K., Mukyala, V., Muramuzi, B. and Namusobya, Z. (2019), “Audit committee effectiveness, isomorphic forces, managerial attitude and adoption of international financial reporting standards", Journal of Accounting in Emerging Economies, Vol. 9 No. 4, pp. 502-523.

Bartov, E., Gul, F.A. and Tsui, J.S.L. (2000), "Discretionary-accruals models and audit qualifications", Journal of Accounting and Economics, Vol. 30 No. 3, pp. 421-452.

Beasley, M.S., Carcello, J.V., Hermanson, D.R. and Neal, T.L. (2009), "The audit committee oversight process", Contemporary Accounting Research, Vol. 26 No. 1, pp. 65-122.

Buallay, A. and Al-Ajmi, J. (2019), "The role of audit committee attributes in corporate sustainability reporting", Journal of Applied Accounting Research, Vol. 21 No. 2, pp. 249-264.
Sustainability reporting practices 
Cho, C.H., Laine, M., Roberts, R.W. and Rodrigue, M. (2015), "Organized hypocrisy, organizational façades, and sustainability reporting”, Accounting, Organizations and Society, Vol. 40, pp. 78-94.

Correa-Garcia, J.A., Garcia-Benau, M.A. and Garcia-Meca, E. (2020), "Corporate governance and its implications for sustainability reporting quality in Latin American business groups", Journal of Cleaner Production, Vol. 260, pp. 0959-6526.

Cronbach, L.J. (1951), "Coefficient alpha and the internal structure of tests", Psychometrika, Vol. 16 No. 3, pp. 297-334.

De Villiers, C. and Sharma, U. (2020), "A critical reflection on the future of financial, intellectual capital, sustainability and integrated reporting”, Critical Perspectives on Accounting, Vol. 70, p. 101999.

Dominic, S.B.S. and Martinov-Bennie, N. (2015), "Internal auditors' perceptions of their role in environmental, social and governance assurance and consulting", Managerial Auditing Journal, Vol. 30 No. 1, pp. 80-111.

Engelbrecht, L., Yasseen, Y. and Omarjee, I. (2018), "The role of the IAF in integrated reporting: a developing economy perspective", Meditari Accountancy Research, Vol. 26 No. 4, pp. 657-674.

Field, A. (2009), Discovering Statistics Using SPSS, 3rd ed., Sage Publications, London.

Financial Institutions Act (2004), Financial Institutions Act to the Uganda Gazette14 Volume XCVII Dated 26th March, Kampala.

GRI (2019), "GRI sustainability disclosure database”, available at: https://database.globalreporting. org/search/ (accessed 30 September 2019).

Guthrie, J., Cuganesan, S. and Ward, L., (2007), "Legitimacy theory: a story of reporting social and environmental matters within the Australian food and beverage industry", Pacific Interdisciplinary Research in Accounting Conference, 5th: 2007, pp. 1-35, (APIRA) Conference, Aucland-New Zealand.

Haji, A.A. and Anifowose, M. (2016), “Audit committee and integrated reporting practice: does internal assurance matter?”, Managerial Auditing Journal, Vol. 31 Nos 8/9, pp. 915-948.

International Auditing and Assurance Standards Board (2013), Handbook of International Quality Control, Auditing, Review, Other Assurance and Related Services Pronouncements, 2013 edition, International Federation of Accountants, Vol. 1, pp. 1-919.

Jensen, M.C. and Meckling, W.H. (1976), "Theory of the firm: managerial behavior, agency costs and ownership structure", Journal of Financial Economics, Vol. 3 No. 4, pp. 305-360.

Journeault, M., Levant, Y. and Picard, C.F. (2021), "Sustainability performance reporting: a technocratic shadowing and silencing”, Critical Perspectives on Accounting, Vol. 74, p. 102145.

Karaman, A.S., Kilic, M. and Uyar, A. (2020), "Green logistics performance and sustainability reporting practices of the logistics sector: the moderating effect of corporate governance", Journal of Cleaner Production, Vol. 258, 120718.

Kennedy, P. (2008), A Guide to Econometrics, 2nd ed., Blackwell, Oxford.

Lin, Z., Xiao, J.Z. and Tang, Q. (2008), "The roles, responsibilities and characteristics of audit committee in China", Accounting, Auditing \& Accountability Journal, Vol. 21 No. 5, pp. 721-751.

Nalukenge, I., Nkundabanyanga, S.K. and Ntayi, J.M. (2018), "Corporate governance, ethics, internal controls and compliance with IFRS", Journal of Financial Reporting and Accounting, Vol. 16 No. 4, pp. 764-786.

Orazalin, N. and Mahmood, M. (2018), "Economic, environmental, and social performance indicators of sustainability reporting: evidence from the Russian oil and gas industry", Energy Policy, Vol. 121, pp. 70-79.

Samaha, K., Khlif, H. and Hussainey, K. (2015), "The impact of board and audit committee characteristics on voluntary disclosure: a meta-analysis", Journal of International Accounting, Auditing and Taxation, Vol. 24, pp. 13-28.

Shamil, M.M., Shaikh, J.M., Ho, P.L. and Krishnan, A. (2014), "The influence of board characteristics on sustainability reporting", Asian Review of Accounting, Vol. 22 No. 2, pp. 78-97. 
Suchman, M.C. (1995), "Managing legitimacy: strategic and institutional approaches", Academy of Management Review, Vol. 20 No. 3, pp. 571-610.

Tauringana, V. (2021), "Sustainability reporting adoption in developing countries: managerial perception-based determinants evidence from Uganda", Journal of Accounting in Emerging Economies, Vol. 11 No. 2, pp. 149-175.

World Meteorological Organization (2021), "State of the global climate 2020", available at: https:// library.wmo.int/doc_num.php?explnum_id=10618 (accessed 7 July 2021).

Sustainability reporting practices

Zaefarian, G., Kadile, V., Henneberg, S.C. and Leischnig, A. (2017), "Endogeneity bias in marketing research: problem, causes and remedies”, Industrial Marketing Management, Vol. 65, pp. 39-46.

\section{Further reading}

Dienes, D., Sassen, R. and Fischer, J. (2016), "What are the drivers of sustainability reporting? A systematic review", Sustainability Accounting, Management and Policy Journal, Vol. 7 No. 2, pp. 154-189. 


\section{AJAR \\ Appendix}

\section{7,2}

180

Component

Review of sustainability information and supervision of internal audit

Liaison with

external

auditors

Our audit committee develops an understanding of the economic substance of unusual transactions Our audit committee reviews the internal audit

0.894

report of this financial institution

Our audit committee reviews the internal audit programs of this financial institution

Our audit committee reviews financial and other

non-financial information

Our audit committee advises on the application of

\subsection{6}

0.854

accounting policies

Our audit committee makes recommendations on

0.831

our sustainability information

Our audit committee ensures that the internal audit

function of this financial institution is adequately staffed

Our audit committee reviews information on

corporate social responsibility

Our audit committee has the financial expertise to

review the corporate financial information

Our audit committee reviews any significant control $\quad 0.766$

deficiencies identified by the internal auditor

Our audit committee holds meetings coordinating

the internal and external auditors

Our audit committees discusses with the external

auditor matters of quality reporting

Our audit committees form a forum to link the

directors with the external auditors

Our audit committee ensures that the internal audit

function of this financial institution is adequately staffed

Our audit committees handles complaints of

external auditors

Our audit committees determines the nature of the

external audit

Eigen values

Cumulative percentage

Table A1.

Rotated component matrix for audit committee effectiveness

Note(s): Kaiser - Meyer - Olkin Measure of Sampling Adequacy = 0.936; Approx. Chi square $=1399.118$; $\mathrm{df}=105 ; \mathrm{Sig}=0.000$

Extraction Method: Principal Component Analysis

Rotation Method: Varimax with Kaiser Normalization

Source(s): Primary data 


\begin{tabular}{|c|c|c|c|}
\hline \multirow[b]{2}{*}{ Statement } & \multicolumn{2}{|c|}{ Component } & \multirow{2}{*}{$\begin{array}{r}\text { Sustainability } \\
\text { reporting } \\
\text { practices }\end{array}$} \\
\hline & $\begin{array}{l}\text { Review and evaluation of } \\
\text { control processes }\end{array}$ & $\begin{array}{l}\text { Risk management } \\
\text { practices }\end{array}$ & \\
\hline $\begin{array}{l}\text { Our internal audit evaluates the effectiveness, efficiency and economy } \\
\text { of operations }\end{array}$ & 0.909 & & \\
\hline Our internal audit verifies the existence of financial institution assets & 0.905 & & \\
\hline $\begin{array}{l}\text { Our internal audit reports on the system for generating financial } \\
\text { information }\end{array}$ & 0.890 & & \\
\hline $\begin{array}{l}\text { Our internal audit encourages the financial institution to maintain its } \\
\text { records with reasonable detail }\end{array}$ & 0.889 & & \\
\hline $\begin{array}{l}\text { Our internal audit safeguards this corporation's tangible assets from } \\
\text { misuse }\end{array}$ & 0.882 & & \\
\hline $\begin{array}{l}\text { Our internal audit generates periodic reports regarding the } \\
\text { effectiveness of internal controls }\end{array}$ & 0.867 & & \\
\hline $\begin{array}{l}\text { Our internal audit confirms all the documentations of the various } \\
\text { transactions }\end{array}$ & 0.863 & & \\
\hline Our internal audit always check the authorization of all expenditures & 0.854 & & \\
\hline $\begin{array}{l}\text { Our internal audit evaluates the reliability of the information produced } \\
\text { by accounting and computer systems }\end{array}$ & 0.839 & & \\
\hline $\begin{array}{l}\text { Our internal audit ensures that economic transactions of this financial } \\
\text { institution are supported by adequate documentation }\end{array}$ & 0.767 & & \\
\hline $\begin{array}{l}\text { Our internal audit ensures internal controls promotes proper } \\
\text { segregation of duties }\end{array}$ & 0.754 & & \\
\hline $\begin{array}{l}\text { Our internal audit provides an independent appraisal function of the } \\
\text { risks likely to affect our business }\end{array}$ & & 0.932 & \\
\hline $\begin{array}{l}\text { Our internal audit provides investigative services to line management } \\
\text { in terms of suspected fraud }\end{array}$ & & 0.923 & \\
\hline $\begin{array}{l}\text { Our internal audit reviews management arrangements for ensuring } \\
\text { that the sustainability objectives are being achieved }\end{array}$ & & 0.919 & \\
\hline $\begin{array}{l}\text { Our internal audit staff have the necessary expertise in identifying } \\
\text { risks }\end{array}$ & & 0.914 & \\
\hline $\begin{array}{l}\text { Our internal audit gives reasonable assurance on risk management } \\
\text { processes }\end{array}$ & & 0.906 & \\
\hline Our internal audit contributes to the improvement of risk management & & 0.890 & \\
\hline $\begin{array}{l}\text { Our internal audit recommends on compliance with the Financial } \\
\text { Institutions Act }\end{array}$ & & 0.806 & \\
\hline $\begin{array}{l}\text { Our internal audit commends that sustainability reports are prepared } \\
\text { in accordance with global reporting initiative guidelines }\end{array}$ & & 0.790 & \\
\hline $\begin{array}{l}\text { Our internal audit updates staff on the changes in the applicable laws } \\
\text { and regulations }\end{array}$ & & 0.714 & \\
\hline $\begin{array}{l}\text { Our internal audit submits a report on the execution of the work plan } \\
\text { to the audit committee }\end{array}$ & & 0.704 & \\
\hline Our internal audit identifies significant exposures to risk & & 0.689 & \\
\hline Our internal audit reviews the management of key risks & & 0.671 & \\
\hline Eigen values & 15.182 & 3.504 & \\
\hline Percentage of variance & 41.435 & 39.810 & \\
\hline Cumulative percentage & 41.435 & 81.244 & \\
\hline $\begin{array}{l}\text { Note(s): Kaiser - Meyer - Olkin Measure of Sampling Adeq } \\
\text { df = 253; Sig }=0.000 \\
\text { Extraction Method: Principal Component Analysis } \\
\text { Rotation Method: Varimax with Kaiser Normalization } \\
\text { Source(s): Primary data }\end{array}$ & $y=0.905 ;$ Approx & $\operatorname{are}=2287.159$ & $\begin{array}{r}\text { Table A2. } \\
\text { Rotated component } \\
\text { matrix for internal } \\
\text { audit function }\end{array}$ \\
\hline
\end{tabular}

\section{Corresponding author}

Zainabu Tumwebaze can be contacted at: ztumwebaze@mubs.ac.ug

For instructions on how to order reprints of this article, please visit our website:

www.emeraldgrouppublishing.com/licensing/reprints.htm

Or contact us for further details: permissions@emeraldinsight.com 